Digitalizacja archiwalnych numerów czasopisma naukowego Analecta Cracoviensia 1-24 (1969-1992) i ich publikacja w otwartym dostępie - zadanie finansowane w ramach umowy 672/P-DUN/2017 ze środków Ministra Nauki i Szkolnictwa Wyższego przeznaczonych na działalność upowszechniającą naukę

\title{
NOWA INTERPRETACJA BIBLIJNA DOGMATU STWORZENIA CZLOWIEKA: MONOGENIZM CZY POLIGENIZM?
}

IV Sobór Lateraneński (11-30. XI. 1215) w dekrecie Firmiter credimus zdefiniował jako dogmat prawdę, że Pan Bóg jest stwórcą człowieka. Konkretne orzeczenie Soboru w tej sprawie brzmi: „Ten jeden wszechmogący i wieczny Bóg swoją potęgą równocześnie i od początku czasu utworzył $\mathrm{z}$ nicości jeden i drugi rodzaj stworzeń: istoty duchowe i materialne, tzn. aniołów i świat a na koniec (naturę) ludzką, jakby łączącą te dwa światy, złożoną z duszy i ciała" ${ }^{1}$. Dekret ten powtórzony później przez I Sobór Watykański (24. IV. 1870) w konstytucji dogmatycznej Dei Filius ${ }^{2}$, był zawsze interpretowany przez teologów w sensie ścisłego monogenizmu, tzn. że P. Bóg na początku stworzył jedną parę ludzką, tj. jednego mężczyznę $\mathrm{i}$ jedną kobietę, $\mathrm{z}$ których rozwinął się później cały rodzaj ludzki.

Ta teoria monogenizmu nie była nigdy kwestionowana, dopóki na przełomie XIX i XX w. nauki przyrodnicze nie zaczęły poddawać w wątpliwość istnienia ścisłego monogenizmu biologicznego i na jego miejsce wprowadzać koncepcję polifiletyzmu i poligenizmu ${ }^{3}$. W oparciu o te dane nauk przyrodniczych już w 30-latach naszego stulecia, a potem wyraźnie w r. 1948 Teilhard de Chardin w książce La place de l'homme dans la nature wypowiedział się przeciw monogenizmowi, jako teorii stojącej poza

1 DS 800 .

2 DS 3002.

3 Polifiletyzm jest to pogląd który twierdzi, że najpierw istniało wièe gatunków, które z biegiem czasu połączyły się i dały początek jednemu gatunkowi. Poligenizm jest to twierdzenie, które przyjmuje istnienie na początku wielu par ludzkich, z których później rozwinął się rodzaj ludzki. Por. R. Lecat, Polygénisme, w: DBS 1967, kol. 92-102. 
zasięgiem nauki ${ }^{4}$. Przeciw monogenizmowi wystąpili także między innymi $\mathrm{H}$. Rondet $\mathrm{w}$ artykule „Les origines humaines et la théologie”, dominikanin A. M. Dubarle w ,Les sages d'Israel”, egzegeta J. Chaine w książce „Le livre de la Genèse”, Paris 1948 i wielu innych. Wypowiedzi te $\mathrm{z}$ początku bardzo nieśmiałe potem coraz bardziej wyraźne i zdecydowane, spowodowały, że w r. 1950 zabrał w tej sprawie głos Ojciec Swięty Pius XII i w słynnej encyklice Humani generis wypowiedział na nowo katolicką naukę o monogenizmie. Wypowiedź papieża dotyczyła wielu spornych kwestii $\mathrm{m}$. in. także i ewolucjonizmu, ale odnośnie naszego zagadnienia jest następująca: „Co się tyczy innej hipotezy, tzw. poligenizmu, synom Kościoła wspomniana swoboda dyskusji nie przysługuje. Nie wolno bowiem wiernym przyjąć teorii, że po Adamie istnieli na tej ziemi ludzie nie pochodzący od niego jako wspólnego przodka, albo, że sỉowo 〈Adam〉 oznacza jakąś nieokreśloną wielość praojców. Zupełnie bowiem nie widać (cum nequaquam appareat) jak tego rodzaju zdanie dałoby się pogodzić z nauką źródeł Objawienia i Urzędu Nauczycielskiego Kościoła o grzechu pierworodnym, który pochodzi z grzechu prawdziwie popełnionego przez jednego Adama i tak udziela się wszystkim ludziom poprzez rodzenie, iż staje się grzechem własnym każdego z nich" ${ }^{5}$.

$\mathrm{Z}$ powyższej wypowiedzi wynika, że papież odrzuca teorię poligenizmu, chociaż nie stwierdza pozytywnie, że jest ona teorią fałszywą. Również nie mówi, że trzeba ją absolutnie odrzucić, jako stojącą w sprzeczności z nauką Kościoła o grzechu pierworodnym. Jedynie zaznacza, że przyjęcie poligenizmu nasunęłoby wiele trudności z pogodzeniem go z nauką Kościoła o grzechu pierworodnym. Słowa papieża na ten temat cytowane według oryginału brzmią: ,nequaquam appareat quomo$d o=$ zupełnie bowiem nie widać... jakby to to zdanie dało się pogodzić z nauką Kościoła o grzechu pierworodnym". Na razie, można interpretować słowa Namiestnika Chrystusowego, ,nie widać” jakichś możliwości, ale to nie znaczy, że te możliwości nie istnieją i przy pomocy zastosowania nowych reguł hermeneutycznych, nowego odczytania źródeł Objawienia staną się one bardzo realne i będą mogły dostarczyć jakichś racji za poligenizmem.

Takie ustawienie zagadnienia było pewnym osłabieniem nauki Kościoła o monogenizmie i niewątpliwie wpłynęło na to, że wielu teologów, którzy przed encykliką Humani generis, monogenizm kwalifikowali jako dogmat albo prawdę bliską wiary (proxima fidei), po tej encyklice zaczęło obniżać stopień jej pewności teologicznej.

I tak np. K. Rahner określa monogenizm jako prawdę teologicznie

4 Por. K. Kłósak, P. Teilhard de Chardin a zagadnienie monogenistycznych począków ludzkości, w: „Studia Teol. Vars.”, 1 (1963) i 2 (1963).

5 DS 3897; Podaję według tłumaczenia z „Breviarium Fidei”, V, 39. 
pewną, która powinna być przyjęta wewnętrznym przyzwoleniem ${ }^{6}$, ale nie takimi, które nie mogą ulec zmianie. H. Rondet stoi na stanowisku, że po encyklice „Humani generis” monogenizm można uważać za zdanie teologicznie omylnie pewne lub prawdopodobne ${ }^{7}$. Ks. I. Różycki ${ }^{8}$ daje temu zdaniu kwalifikację — teologicznie prawdopodobne.

Z szerokiej dyskusji jaka na ten temat rozwinęła się przed a szczególnie po encyklice Humani generis wynika, że monogenizm nie został nigdy przez Kościół zdefiniowany jako dogmat ${ }^{9}$, ani też nie można mówić, że jest nim ze zwyczajnego nauczania Kościoła powszechnego. Stanowisko Piusa XII w analizowanym przez nas tekście encykliki Humani generis, nie dotyczy poligenizmu rozważanego w samym sobie ani jego genezy i wartości naukowej, od strony przyrodniczej, ale dotyczy jego związku z grzechem pierworodnym i z tej racji może on być niebezpieczny dla wiary. Co się tyczy monogenizmu, to została pozostawiona teologom pełna swoboda badań nad nim samym oraz nad jego konsekwencjami teologicznymi.

Idąc po linii tej swobody badań, próbują teologowie, wsparci przez egzegetów i teologów biblijnych, przebadać na nowo w oparciu o reguły nowej hermeneutyki biblijnej te miejsca i teksty Pisma św., które w jakiś sposób na pierwszy rzut oka nasuwają wnioski o monogenistycznym początku rodu ludzkiego na ziemi.

Do tych miejsc zaliczamy w zasadzie dwa opowiadania o stworzeniu człowieka: pierwsze pochodzące $z$ tzw. źródła $J$, zawarte $w$ Rdz 2, 7 . 18-24, datowane mniej więcej na IX w. przed Chr. oraz drugie, którego autorem jest jakaś szkoła kapłańska z końca VI w. przed Chr., zapisanego w Rdz 1, 26-28, powszechnie określanego jako źródło $P$. Niezależnie od tego autorzy ksiąg natchnionych w różnych miejscach swoich pism, raz po raz wracają do myśli o stworzeniu człowieka, komentując W ten sposób wypowiedzi wcześniejszych pisarzy ${ }^{10}$, ale i równocześnie uściślając swoje stanowisko na ten niezwykle ważny i stale interesujący człowieka problem.

6 K. Rahner, Theologisches zum Monogenismus, w: ,Zeitschrift f. kath. Theologie", 76 (1954) 1-18; 187-223.

7 H. Rondet, Le péché originel dans la tradition, Paris 1967, 289.

8 Cyt. za T. B. Eukaszuk, Zwiazek dogmatu grzechu pierworodnego $z$ monogenizmem $w$ katolickiej teologii ostatniej doby, Warszawa 1971 (w maszynopisie), 10, przyp. 3.

Wprawdzie I Sobór Watykański przygotowal kanon o treści: „Si quis universum genus humanum ab uno protoparente ortum esse negaverit, A. S.", ale kanon ten nie został promulgowany. Por. także w tej sprawie przemówienie Pawła VI do teologów z okazji Kongresu Teologicznego w Rzymie w 1966 r.: AAS, 50 (1966) 654.

10 Por. Ps 8; także księgę Joba, Koheleta, Jezusa Syracha. 
I. TEOLOGIA OPISU STWORZENIA CZŁOWIEKA Rdz 2, 7. 18-24.

Nie ulega wątpliwości, że podstawą do wszelkich wypowiedzi na temat stworzenia człowieka była dla biblijnych pisarzy ustna tradycja, przekazywana $z$ pokolenia na pokolenie, której relacje przelane na papier znalazły swój zewnętrzny wyraz w Rdz 2, 4b-24. Pobieżna lektura tego opowiadania może nasunąć nie egzegecie wniosek, że autor przy spisywaniu tego opowiadania myślał o stworzeniu przez Boga jednej pary ludzkiej, od której wywodzą się wszyscy żyjący na świecie ludzie. Nawet Fr. Ceuppens ${ }^{11}$ jest zdania, że z Rdz 2 dość jasno wynika, że P. Bóg stworzył na początku jednego mężczyznę i jedną kobietę. Czy jednak tak jest w rzeczywistości? H. Haag 12 broniąc przeciwnego zdania ucieka się do analizy struktury literackiej tego opowiadania, twierdząc, że autor biblijny przy opracowaniu tego tematu korzystał $\mathrm{z}$ wielu źródeł, które przerabiał i które potem połączył według swego uznania w jedno opowiadanie. Tak więc na początku miał jedno opowiadanie o stworzeniu człowieka, które opisał w $\mathrm{Rdz} 2,7$, gdzie człowiek oznacza nie jednostkę ale ludzi, zarówno mężczyzn jak i kobiety. Potem dołączył do tego opisu zaczerpnięte $\mathrm{z}$ innego źródła opowiadanie o stworzeniu kobiety $\mathrm{Rdz} 2$, 18-24. O tym, że mamy tu do czynienia $\mathrm{z}$ dwoma różnymi opisami świadczy fakt, że gdy w pierwszym opowiadaniu Rdz 2, 7 autor wyraża się o stworzeniu mężczyzny bardzo schematycznie i zwięźle w słowach: „i ulepił Bóg-Jahwe człowieka, proch ziemi i tchnął w jego nozdrza dech życia, dzięki czemu stã̂ się człowiek istotą żywą", to w tym drugim opowiadaniu dochodzi do głosu nie tylko moment powołania do życia niewiasty, ale cała bogata sceneria, związana z jej zaistnieniem. Najpierw jest stwierdzenie faktu, że nie dobrze jest, aby mężczyzna był sam $(2,18)$, potem następuje podjęcie przez Boga decyzji: „uczynię mu pomoc odpowiednią dla niego" $(2,18)$, potem stworzenie całego świata zwierzęcego (ww. 19. 20), o czym nie ma w ogóle mowy przy stworzeniu mężczyzny, nawet jest całkiem przeciwnie, w Rdz 2, 5 czytamy: ,gdy nie było na ziemi żadnego krzewu, ani żadna trawa polna jeszcze nie wzeszła,... wtedy Jahwe Bóg ulepił człowieka”. Potem następuje wzmianka, która właściwie należy do istoty opowiadania: „P. Bóg sprawił, że mężczyzna pogrążył się w głębokim śnie”, a gdy spał (w. 21) Bóg Jahwe z żebra, które wyjął z mężczyzny, zbudował niewiastę.

$\mathrm{Z}$ zestawienia tych opisów i już pobieżnej ich analizy widać, że mamy tu do czynienia $\mathrm{z}$ dwoma różnymi opowiadaniami, które autor biblijny podczas dokonywania redakcji księgi miał pod ręką i połączył w jedną

11 De historia primaeva, Roma 1933; także Genèse I-III, Paris 1946; Le Polygénisme et la Bible, w: „Angelicum”, 24 (1947) 25.

12 Biblische Schöpfungslehre und kirchliche Erbsünde, Stuttgart 1967, 41-59. 
całość. Po złączeniu tych dwóch opowiadań, z konieczności trzeba było nadać słowu ha-adam z R $\bar{d} z$ 2, 7 znaczenie „mężczyzna”, by odpowiadało ono użytemu w Rdz 2, 18-24 słowu „kobieta” i na tej drodze wyrażenie ha-adam, które pierwotnie miało sens kolektywny, nabrało znaczenia indywidualnego, jednostkowego.

Rozumowanie swoje popiera $\mathrm{H}$. Haag jeszcze analizą kontekstu $\mathrm{Rdz}$ r. 2. 3. Według niego $\mathrm{w} \operatorname{Rdz} 2,8$ jest mowa o umieszczeniu w raju ha adam = człowieka, a przecież wiemy, że byli umieszczeni ludzie i podobnie też przy wypędzeniu z raju w $\mathrm{Rdz} 3,24$ jest użyte słowo ha adam, wygnany został człowiek, gdy tymczasem faktycznie zostali wygnani i mężczyzna i kobieta a więc ludzie. Tak więc według $\mathrm{H}$. Haaga właściwie w opowiadaniu $J$ jest mowa o stworzeniu ludzi a nie jednej pary iudzkiej, zaś wzmiankę o stworzeniu kobiety należy uważać za dopełnienie opisu stworzenia mężczyzny z Rdz 2, 7 .

Takie rozumowanie, oparte o zasadę Formgeschichte i Redaktionsgesrhichte, choć słuszne i w zupełności poprawne, budzi jednak wątpliwość, czy jest $\mathrm{w}$ pełni uzasadnione? Nie mamy dostatecznych racji, by widzieć w Rdz 2 zlepek dwóch czy trzech różnych tradycji powiązanych przez autora w jedno. Wydaje się, że rozwiązania tej trudności można szukać jeszcze na innej drodze.

Przede wszystkim trzeba się zapytać, jak słusznie sugeruje wielu egzegetów, jaki cel przyświecał autorowi piszącemu to opowiadanie. Już na samym początku należy stwierdzić, że autor Rdz rr. 2. 3 bazując na źródłach historycznych i przekazując nam pewne fakty o znaczeniu historycznym, nie miał na celu pouczać nas o historii ani też tym więcej o paleontologii czy antropologii. Nie interesował go zatem ani monogenizm ani ewolucjonizm, który z konieczności prowadzi do poligenizmu. Celem jego opowiadania było przekazanie pewnych prawd religijnych. Na tej podstawie można twierdzić, że autorowi $\mathrm{Rdz} 2$ nie chodziło o to, jak powstał człowiek, ale raczej o to, że jest on stworzeniem Boskim. W oparciu o tę zasadę twierdzimy dalej, że zarówno opis raju, jak i wzmiankę o drzewach $\mathrm{w}$ nim rosnących oraz całą scenerię z tym opisem związaną, należy tłumaczyć symbolicznie. Symbole tu zawarte wyrażają pewną prawdę, w tym konkretnym wypadku taką samą, jaką przekazuje nam autentyczne historyczne opowiadanie.

Wiemy również, że wielką rolę $w$ takich opowiadaniach odgrywa też sam język, przy pomocy którego przekazujemy jakieś prawdy. Język biblijny ściśle mówiąc język hebrajski był językiem ubogim, zatem nie posiadającym tyle słów i wyrażeń, by przy ich pomocy $\mathrm{w}$ pełni przekazać tę prawdę religijną, o którą w danej chwili chodziło autorowi. Dlatego autorzy biblijni uciekali się z konieczności rzeczy do symboli i symboliki, nie po to, aby przy ich pomocy zamazywać i uczynić mniej 
zrozumiałą rzeczywistośé, o którą im chodzi, ale aby tą drogą tę rzeczywistość głębiej i jaśniej przedstawić. Dlatego śmiem zaryzykować tu twierdzenie, że biblijny język symboli to prawdziwa filozofia i teologia autora natchnionego, chociaż może nawet czasami przez niego explicite nie zamierzona. W oparciu o tę sugestię można powiedzieć, że w odniesieniu do interesującego nas problemu $R d z$ 2, 7 (stworzenie człowieka) i 2, 18-24 (stworzenie niewiasty) opowiadania te nie oznaczają nic wię$c \in j$, jak tylko boskie pochodzenie ludzi, którzy z natury są sobie równi i choć są śmiertelni, otrzymali przez tchnienie Boże zadatek nieśmiertelności ${ }^{13}$.

Twierdzić zatem, że $\mathrm{w}$ interesującym nas opowiadaniu Rdz 2, 7 . 18--24, jak słusznie zauważa H. Renckens ${ }^{14}$, autor mówi o monogenizmie, jest decydować się na twierdzenie aprioryczne, które de facto nie ma pokrycia w rzeczywistości. Wydaje się całkiem słuszne zdanie wielu egzegetów ${ }^{15}$, że problem monogenizmu czy poligenizmu, leżał poza zasięgiem zainteresowań autora opowiadania jahwistycznego. Jego jako katechetę interesowała przede wszystkim treść religijna i dlatego tej treści musimy szukać w jego opowiadaniu, choćby nawet kosztem historycznej wartości całego opisu.

Niezależnie od tego ujęcia nie wolno nam zapominać o tym, że większość opowiadań biblijnych szczególnie z pierwszych 11 rozdziałów Rdz, to opowiadania o charakterze etiologicznym. Autor Rdz jako wnikliwy obserwator otaczającego go świata, spotykał się z tymi opowiadaniami i równocześnie dostrzegał wokoło siebie pewne konkretne zjawiska. Widząc je już w pewnej formie zakrzepłej, że się tak wyrażę, już w formie wykończonej, często pytał się o genezę tego wszystkiego. Nie mogąc jej dociec w źródłach, sam po skutkach sięgał do przyczyny i odtwarzał ją sobie tylko w jemu właściwy i możliwy sposób. I tak konkretnie widząc żyjących na ziemi ludzi, mężczyzn i niewiasty, cały świat roślinny i zwierzęcy, widząc pewną hierarchię między bytami odpowiadał sam sobie na pytanie skąd to wszystko się wzięło. Odpowiadał, że to wszystko pochodzi od Boga, tak jak później inni autorzy widząc na ziemi deszcz, urodzaj, pogodę, czy słońce, będą mówić, że sprawcą tego wszystkiego jest Bóg. Podobnie jak wiele wieków później powie św. Paweł w 1 Kor 15, 28, że: „,Bóg jest wszystkim we wszystkich”. Rzecz jasna, że autorowie natchnieni wyrażając się w ten sposób sięgają po pierwszą przyczynę wszystkiego, nie negując bynajmniej istnienia przyczyn pośrednich.

Tak więc interesujące nas opowiadanie należy uznać za opowiadanie 74.

13 Por. Cz. Jakubiec, Pradzieje Biblijne. Teologia Genesis 1-11, Poznań 1968, 49.

14 H. Renckens, Urgeschichte und Heilsgeschichte, Mainz 1964, 216-223.

15 Por. K. Rahner, Grzech pierworodny a ewolucja, w: "Concilium", tlum. pol., $1-10(1966 / 7) 288-295$. 
etiologiczne, w którym autor wyjaśnia tylko problem pojawienia się ludzi na ziemi, nie wdając się $w$ żadne naukowe dyskusje, na temat istot człekokształtnych, ich ewolucji, czy też hominizacji świata lub powsíania rodzaju ludzkiego z jednej czy $z$ więcej par ludzkich. Można zatem powiedzieć, że w takim ujęciu autorowi jahwistycznego opowiadania chodziło więcej o wytłumaczenie sensu pojawienia się człowieka na ziemi, aniżeli przekazania faktu, który byłby zgodny z historyczną prawdą.

Niezależnie od tego rozwiązania można jeszcze nasze opowiadanie wyjaśnić w oparciu o tzw. zasadę Sitz im Leben. W oparciu o nią stwierdzamy, że interesujące nas opowiadanie nosi na sobie wszystkie cechy opowiadań folklorystycznych, ubranych w szatę starożytnego sposobu pisania historii, gdzie często prawda jest pomieszana $\mathrm{z}$ legendą, a wprowadzone do opowiadania epizody, prawie zawsze zaczerpnięte są z wiecznie żywej tradycji ludowej. Nic więc dziwnego, że taki sposób opisywania rzeczywistości spotykamy także i w omawianym przez nas obecnie opisie Rdz 2. Wiemy, że u starożytnych ludzi żyło przekonanie, że każda grupa ludzka posiada swojego jakiegoś plemiennego przodka, od którego wywodzi się i którego rysy i cechy nosi na sobie. Tak więc wierzono, że Kanaanici pochodzą od Kanaana, Aramejczycy od Arama, Edomici od Ismaela, ludzkość po potopie od Noego poprzez trzech jego synów itp. Biblia niemal każdemu szczepowi wyszukuje jakiegoś przodka, próbując w ten sposób także między innymi wykazać historyczność danego rodu. W oparciu o to rozumowanie można zapytać za H. Renckensem, czy „księga Rodzaju, gdy całą ludzkość wywodzi od jednego człowieka (adam), to czy ona chce przez to coś więcej powiedzieć niż wtedy gdy mówi, że Kanaanici są potomkami jakiegoś tam Kanaana"? ${ }^{16}$. Wydaje się, że według starożytnych przekonań każdy szczep, każdy naród, każda grupa etniczna tylko wtedy posiadały jakieś znaczenie, gdy mogly się wylegitymować wobec innych swoim przodkiem, od którego pochodziły i którego prawdziwe czy urojone przymioty wcielały w życie. Autor naszego opowiadania spotykając się z faktem istnienia rodu ludzkiego i opisując jego dzieje, nie mógł nie wyznaczyé ludziom jakiegoś wspólnego przodka, na którego nie przeniósłby wszystkich dodatnich czy ujemnych cech, z jakimi spotykał się na co dzień u otaczających go ludzi. Jest to niewątpliwie jakieś retrospektywne myślenie, ale całkiem zrozumiałe i właściwe tej epoce, w której autor biblijny żył i dla której tworzył swoje opowiadania.

Jeśli się zważy na dodatek, że znał wiele współczesnych mu legendarnych babilońskich i innych opisów stworzeń świata i ludzi, gdzie nawet bogowie mieli swoich przodków i sami byli praojcami pewnych grup ludzkich, nie sposób nie przyjąć, aby takiego toku. rozumowania

16 Por. dz. cyt., $227 n$. 
nie wprowadził w swoje opowiadanie. Jest to semicki sposób myślenia, zorientowany bardzo religijnie i zgodnie ze sposobem myślenia żyjących współcześnie z naszym autorem-pisarzem ludzi. Można zatem powiedzieć, że w Adamie zamknął autor naszego opowiadania wszystkie znane mu cechy ludzkości, nie przesądzając tym samym czy Adam jest jednostką, czy pojęciem kolektywnym.

\section{KAPEAÑSKI OPIS STW.ORZENIA CZEOWIEKA Rdz 1, 26-28.}

Prawdziwość wywodów przytoczonych wyżej jeszcze bardziej się uwypukli, gdy rozważymy je na tle analizy późniejszego opisu stworzenia człowieka w $R d z 1,26-28$, który to opis w pewnym sensie możemy nazwać komentarzem do opisu jahwistycznego.

Jest faktem bezspornym, że $R d z 1,26-28$ powtarza pewne myśli z opisu stworzenia człowieka $\mathrm{Rdz}$ 2, 7. 18-24, uzupełniając je własnymi dodatkami. Opis ten zorientowany przede wszystkim na refleksję teologiczną, jest inny od opisu $J$, ale nie jest $z$ nim sprzeczny. Gdy opis $J$ na pierwszy rzut oka robi wrażenie opisu o charakterze monogenicznym, to opis $P$ sugeruje czytelnikowi możliwość poligenizmu. W zasadzie żaden z opisów nie zajmuje się ani monogenizmem ani poligenizmem, ponieważ dla autorów omawianych opowiadań problem ten nie istniał wcale. Był on poza zasięgiem i zakresem ich zainteresowań.

Analizując zatem interesującą nas treść opisu stworzenia człowieka w $R d z$ 1, 26-28 musimy wyróżnić, między tym co autor nam w tym opisie mówi, a tym czego nas przez ten opis pragnie nauczyć, czyli innymi słowy jaką przekazuje nam w nim prawdę teologiczną.

Odnośnie pierwszego pytania należy stwierdzić, że autor opowiadania $P$ specjalnie nie wyróżnia człowieka. Traktuje go na równi z innymi stworzeniami Bożymi. Mówiąc ogólnie o dziele stworzenia wylicza różne rodzaje stworzonych przez Boga bytów. Mówi o ciałach niebieskich, o roślinach i zwierzętach według ich rodzaju i w końcu o ludziach. Już z tego zestawienia wynika, że nie ma na myśli człowieka jako jednostkę, ale caly rodzaj ludzki. Człowiek jest tu ,uczyniony" (=asah) jak to czytamy w Rdz 1, 26. Niektórzy egzegeci twierdzą, że choć w odniesieniu do Boga nie ma różnicy między czasownikami „czynić” i „stwarzać”, $(=a s a h$, bara), to jednak czasownik ten tu użyty lepiej uwydatnia kim właściwie w zamiarach Bożych miał być człowiek. Jako korona stworzenia umieszczony na szczycie dzieł stwórczych, różnił się od innych stworzeń, przez to, że był uczyniony na obraz Boży. Można zatem powiedzieć, ze autorowi opowiadania $P$ nie chodziło o udowodnienie na jakiej drodze pochodzi człowiek, ile o przekazanie o nim kilku informacji, zdoby.. tych głównie na drodze obserwacji otaczającego nas świata. Na tej zasadzie autor opowiadania $P$ względnie autorzy mówią, że człowiek jest 
obrazєm Bożym, że ma panować nad światem, ma się na tym świecie rozmnażać i napełniać sobą ziemię. W związku z tym autor opowiadania P dodaje, że P. Bóg pobłogosławił człowieka (w. 28), o czym formalnie nie ma wzmianki w opowiadaniu $J$. Błogosławieństwo to zostaje w ścisłym związku z rozmnażaniem się ludzi na świecie, a więc podkreśla, że życie, które człowiek posiada i które będzie mógł przekazywać, otrzymał od Boga, który jeden jedyny je w pełni posiada. Takie są główne teologiczne myśli opisu $P$. Czy jednak nie znajduje się w nim jakaś konkretna wzmianka o jednostkowym stworzeniu człowieka.

Odpowiedzi na to pytanie możemy szukać jedynie w filologicznej i gramatycznej analizie $\mathrm{Rdz} 1,26$. Czytamy tam w tekście masoreckim slowa: Wajjomer Elohim naaseh adam becalmenu kidmutenu. Użyte iu słowo adam jest określeniem ogólnym, a szczególnie zastosowane w tym miejscu, w przeciwieństwie do $\mathrm{Rdz} 2$, 7 bez rodzajnika ha nie może być inaczej tłumaczone jak tylko przez słowo ,ludzie”. C. Westermann ${ }^{17}$ twierdzi, że występuje ono w Starym Testamencie 554 razy, prawie zawsze w znaczeniu kolektywnym na określenie ludzi, względnie rodzaju ludzkiego. W sensie jednostki jest użyte $w$ zestawieniu ze słowem ben = syn, np. ben adam, „syn człowieczy”. Ten sens kolektywny tego słowa ciągnie się przez cały Stary Testament. Szczególnie nawiązują do niego księgi dydaktyczne i prorockie, kiedy zastanawiają się nad wielkością czy małością człowieka. Fr. Zorell ${ }^{18}$ stoi na stanowisku, że miejsca w Biblii, w których słowo adam oznacza jednostkę, są bardzo rzadkie. Właściwie o jednostkowym znaczeniu tego słowa decyduje tekst i kontekst, np. $\operatorname{Rdz} 4,25 ; 5,1 ; \operatorname{Krn} 1$, 1 . W miejscach tych słowo adam jest właściwie imieniem własnym, konkretnego człowieka.

Dalej za kolektywnym znaczeniem tego słowa przemawia także składnia hebrajska, według której podmiot musi się zgadzać z orzeczeniem w rodzaju i liczbie. Z tej racji tłumaczymy $R d z 1,26$ : ,uczyńmy ludzi... aby panowali... nad całą ziemią". Według takiego ustawienia tłumaczenia nie trudno przyjąć, że autor $P$ nie miał zamiaru informować nas o tym, czy.P. Bóg stworzył jednego czy więcej ludzi, jedynie tylko chciał wykazać pewną wyższość człowieka nad resztą stworzeń. Wyższość ta jego zdaniem wyraża się między innymi także i w panowaniu człowieka nad światem.

Autor opowiadania $P$ jako teolog jest bardzo ścisły i zwięzły w formowaniu swoich twierdzeń i dlatego nie mówi jak Jahwista o stworzeniu mężczyzny czy niewiasty, lecz ogólnie porusza problem stworzenia ludzi. Choć wprawdzie czytamy w w. 27: ,I stworzył Bóg człowieka na

17 Jenni-Westermann, Theologisches Handwörterbuch zum Alten Testament, München 1971, kol. 42.

${ }_{18}$ Lexicon Hebraicum et Aramaicum Veteris Testamenti, Roma 1950, 13. 
obraz swój. Na obraz Boga stworzył go; mężczyzną i niewiastą stworzył ich”, to jednak wyrażenie: „mężczyzna i niewiasta” nie oznacza tu mężczyzn i kobiet, ale jest podkreśleniem dwurodzajowości rodu ludzkiego: rodzaj męski=zakhar i żeński = nekabah, podobnie jak wyżej autor mówił o zwierzętach i roślinach, gdzie stale powtarza się zwrot, że stworzył ich P. Bóg ,według ich rodzajów".

Podkreślenie dwurodzajowości w typowo etiologicznym opowiadaniu było potrzebne autorowi do konkretnego wyjaśnienia zagadki życia i do postawienia wniosku teologicznego, że człowiek jako obraz Boży, mający panować nad światem, był powołany także do przekazywania na nim życia.

Wydaje się, że innych zagadnień autor opisu $P$ jako nie kompetentny nie porusza w swoim opowiadaniu. Dlatego z jego wypowiedzi nie można wyciągnąc wniosku, czy P. Bóg stworzył jedną czy więcej par ludzkich. Nie można także przyjąć, czy powołał do istnienia od razu większą ilość ludzi. Gdy przy opisie stwarzania zwierząt mówi o różnych rodzajach i gatunkach, tu przy człowieku mówi właściwie o gatunku ludzkim, w skład którego wchodzi i mężczyzna i kobieta. Ze struktury literackiej cpowiadania wynika, że autor przekazał nam swoje informacje o człowieku w oparciu o doświadczenie codziennego życia, zgodnie z danymi zaczerpniętymi z tradycji czy to pisemnej czy ustnej.

Te dwa opowiadania stanowiły w ciągu wieków zawsze punkt wyjściowy dla innych autorów biblijnych do ich wypowiedzi o człowieku. $\mathrm{W}$ tych opowiadaniach wraca zawsze ta sama myśl, że człowiek tj. adam rozumiany jako gatunek ludzki przede wszystkim jest stworzeniem Bożym, które wszystko co ma, tj. istnienie, życie, dary i przywileje i całą swoją wielką godność otrzymał od Boga. Dlatego też Jahwe w momencie powołania Mojżesza pyta go: „Kto dał człowiekowi usta, kto czyni go niemym, albo głuchym, widzącym albo niewidzącym, czyż nie ja Jahwe (Wj 4, 11). Izraelici czas mierzyli od momentu stworzenia człowieka. W Ppr 3, 32 czytamy: „Zapytaj dawnych czasów, które były przed tobą, gdy Bóg stworzył na ziemi człowieka". Człowiek jako stworzenie Boże jest własnością Boga, dlatego Jahwista mówi: ,upomnę się o waszą krew, przez wzgląd na wasze życie. Upomnę się też o człowieka, o życie człowieka i u każdego o życie brata" ( $\mathrm{Rdz} 9$, 5). Bóg jako Stwórca człowieka czyni go najwyższym stworzeniem, najdostatniejszym na ziemi: „uczyniłeś go mało co mniejszym od Boga" (Ps 8,6). Niezależnie od tego P. Bóg jest obrońcą i opiekunem ludzi. Można zakończyć te wypowiedzi wnioskiem Koheleta: „Bóg uczynił ludzi prawymi, ale oni szukają rozmaitych wybiegów" (7, 29).

Z tego krótkiego przeglądu różnych wypowiedzi o człowieku w Starym Testamencie wynika, że autorzy biblijni nawiązywali zawsze do znanych 
im najstarszych opowiadań o człowieku i że w wypowiedziach tych nie wyszli poza problematykę tam poruszoną. Nie interesowal ich problem z czego P. Bóg stworzył człowieka, ilu stworzył ludzi, czy i od jak dawna obdarzył ich życiem. Dla nich najważniejsze było jedno, że człowiek, jak wszystko inne na świecie, jest stworzeniem Bożym i przez to jest od Boga zależny.

Reasumując wszystko możemy powiedzieć, za wieloma egzegetami i teologami ${ }^{19}$, że Stary Testament nie zawiera żadnej wypowiedzi o monogenizmie. Konsekwentnie nie da się też udowodnić istnienia tam monogenizmu ani pośrednio ani bezpośrednio. Niektórzy teologowie są zdania, że śmierć człowieka, może być pośrednim dowodem na monogenizm, jako konsekwencja grzechu pojedynczej osoby, ale i to zjawisko można całkiem dobrze wytłumaczyć na innej drodze, choćby w ten sposób, że P. Bóg stwarzając człowieka w ogóle stworzył go śmiertelnym.

\section{NOWY TESTAMENT A MONOGENIZM}

Problem ten, także obcy księgom Nowego Testamentu, wymaga szerszego omówienia przynajmniej odnośnie dwóch tekstów Dz 17, 26 i Rz 5, 12.

Odnośnie pierwszego tekstu Dz 17, 20 należy tu podkreślić okolicz. ności, w jakich św. Paweł słowa te wypowiada. Apostoł narodów znalazł się $\mathrm{w}$ Atenach na areopagu i wypowiada tam swoje poglądy na człowieka w kontekście nauki o Bogu, o Chrystusie i o zbawieniu. Już sam ten kontekst wskazuje, że ujmuje swoje poglądy teologicznie a nie antropologicznie. Walcząc z politeizmem Greków, stwierdza, że „On (tj. P. Bóg) z jednego (człowieka) wyprowadził cały rodzaj ludzki, aby zamieszkiwał całą powierzchnię ziemi" $(17,26)$. Jak tu należy rozumieć te słowa, że P. Bóg ,,z jednego wyprowadził cały rodzaj ludzki”?

Przede wszystkim należy uściślić sam tekst, który w różnych ko-deksach Nowego Testamentu brzmi różnie. Wiele kodeksów po słowie: enos dodaje haimatos, kodeksy greckie, syryjskie, aramejskie dodają po słowie enos słowo ethnos względnie genos. Z tej racji współczesne tłumaczenia na języki nowożytne podają różne brzmienie tego wiersza. Biblia Jerozolimska ma: „On sprawił, że całą ziemię zamieszkuje cały rodzaj ludzki wywodzący się z jednego pnia" (dosł. d’un principe unique). Inni mają: „rodzaj ludzki wywodzący się z jednej i tej samej krwi”, ,z jednego narodu", ,z jednej rasy”, ,z jednego rodzaju”. Starsze tłumaczenia polskie podają zwykle brzmienie tego wiersza opowiadające się za jego monogenistyczną interpretacją. I tak np. Ks. S. Kowalski ma: „On wywiódł cały rodzaj ludzki z jednego człowieka”, przy czym słowo „,czło-

19 Por. K. Rahner, Grzech pierworodny a ewolucja, art. cyt., 289. 
wiek" jest dodane, nie ma go w tekście oryginalnym. Podobnie tłumaczy ks. Dąbrowski w swoim komentarzu do Dziejów Apostolskich ${ }^{20}$, ks. Gryglewicz ${ }^{21}$ oraz I i II wydanie Biblii Tysiąclecia. Wydaje się, że wprowadzenie tu do tekstu słowa ,,człowiek", którego nie ma w oryginale, jest już pewną próbą własnej interpretacji, która chyba była obca zarówno samemu autorowi $\mathrm{Dz}$ jak i ich pierwszym czytelnikom. Przytoczone tu wyżej różne kodeksy, pochodzące z pierwszych wieków chrześcijaństwa, między innymi nawet od św. Ireneusza takiego dodatku nie mają.

Charakterystyczny jest $\mathrm{w}$ nich dodatek: ex enos haimatos, który można przetłumaczyć; ,,ród ludzki wywodzący się z jednej i tej samej krwi”. Jeśli przyjmiemy, że św. Paweł znał egipskie opowiadanie o Bogu Chnu. który lepił ludzi mieszając glinę z krwią bogów, to można przypuszczać, ṫe autor chciał przez to wyraźnie powiedzieć, że człowiek pochodzi od Bıga i ma w sobie coś z Boga. Przyjmując tę interpretację, można się zgodzić z niektórymi egzegetami, że w tej wypowiedzi nie ma u św. Pawła nic więcej, jak tylko zwykłe odniesienie się literackie do Rdz rr. 1-3. Stąd opierając się o augustynowską zasadę interpretacji ${ }^{22}$, że Novum Testamentum in Vetere latet et Vetus in Novo patet, należy tę wypowiedź tak interpretować, jak interpretujemy opis stworzenia ludzi w opowiadaniu $J$ i $P$. Można zatem stanąć na stanowisku, że św. Paweł w omawianym obecnie przez nas tekście mówi jedynie o stworzeniu i pochodzeniu wszystkich ludzi od Boga, a nie interesuje się zagadnieniami monogenizmu, który w jego czasach nie stanowił żadnego problemu.

Myśl o stworzeniu i pochodzeniu wszystkich ludzi od Boga znajdziemy także w tym wierszu, gdy przeanalizujemy go w oparciu o hermeneutyczną zasadę Sitz im Leben. Wiemy, że św. Paweł w swej mowie na Aeropagu nawiązywał do religijnych i społecznych poglądów starożytnych Greków. Według tych poglądów każdy naród pochodził od jakiegoś boga. Na tej zasadzie Ateńczycy uważali się także za pochodzących od swojego krajowego boga. Sw. Paweł zwalczając ten fałszywy pogląd udowadniał im, że jak jest jeden Bóg (o którym mówił wyżej w ww. 16-25), tak też wszyscy ludzie pochodzą od tego samego Boga. Wspominając zaś o wyprowadzeniu całego rodu ludzkiego ,z jednego" (=ex enos) nie miał nic więcej na myśli, jak to co przekazała tradycja żydowska w swej interpretacji księgi Rodzaju. Niewątpliwie chodzi tu o treści mające swe źródło w Bożym objawieniu.

Tak więc reasumując wszystkie wyżej przytoczone wywody, można powiedzieć, że Dz 17, 26 nie zajmują się problemem monogenizmu, prze-

20 Por. E. Dąbrowski, Dzieje Aposto!skie. Wstęp - przeklad z oryginału - komentarz, Poznań 1961, Pallottinum 379.

${ }_{21}$ Ewangelie $i$ Dzieje Apostolskie, z greckiego przetłumaczył ks. F. Gryglewicz, Katowice 1947, 448.

22 Na nią powołuje się też Konstytucja soborowa „Dei Verbum”, r. VI. 
kazując jedynie o pochodzeniu człowieka naukę tradycyjną, powszechnie przyjmowaną przez semitów, której celem było przede wszystkim religijne pouczenie, zmierzające do utrwalenia słuchaczy $\mathrm{w}$ przekonaniu, że człowiek jest przede wszystkim stworzeniem Bożym i jako taki jest całkowicie od Niego zależny.

A jak się przedstawia sprawa z tekstem św. Pawła z listu do $\mathrm{Rz} 5$, 12-19? Tekst ten, którego główna treść obraca się wokół zagadnienia grzechu pierworodnego, interesuje nas o tyle, o ile łączy się on z problemem pochodzenia wszystkich ludzi od jednego człowieka. Chodzi tu zatern głównie o $\mathrm{Rz} 5$, 12, który brzmi: ,dlatego jak przez jednego człowieka grzech wszedł na świat, a przez grzech śmierć i w ten sposób śmierć przeszła na wszystkich ludzi, ponieważ wszyscy zgrzeszyli”. Czy św. Pawłowi w zacytowanym wierszu chodzi o naukę o monogenizmie, czy o grzech Adama? Zdania egzegetów i teologów na ten temat są podzielone ${ }^{23}$. Niektórzy $\mathrm{z}$ nich stoją na stanowisku, że w $\mathrm{Rz} 5,12$ jest zawarta nauka o pochodzeniu całej ludzkości od jednej pary, tj. od Adama i Ewy. O. Mariani ${ }^{24}$ jest zdania, że jeśli Adam przez grzech sprowadził na ludzi śmierć, to znaczy że odebrał im życie. Nie mógłby przecież tego uczynić, gdyby im wcześniej tego życia nie dał. Ch. Hauret ${ }^{25}$ uważa, że św. Paweł tego problemu nie rozstrzyga w ogóle. Posługując się zaś paralelą Adam - Chrystus, niewątpliwie nie rozumiał tu Adama jako jednostkę i konkretnego człowieka. To jest jego zdaniem zwykła paralela, a ta zachowuje swój sens i swoje znaczenie nawet wtedy, gdy jeden $\mathrm{z}$ jej członów jest fikcją.

Egzegetycznie spór można rozstrzygnąć następująco: Przede wszystkim Rz 5, 12-19 należy tłumaczyć w łączności z Rdz rr. 1. 2. Jak wyżej wskazaliśmy $\mathrm{Rdz}$ rr. 1, 2 nie zajmują się problemem monogenizmu. Autorzy tych opowiadań mogli podzielać i w rzeczywistości podzielali poglądy współczesnych sobie ludzi o pochodzeniu wszystkich od jednej pary ludzkiej. Rozumując jednak tak i głosząc takie poglądy, wypowiadali je w tym duchu, w jakim wyrażali wszystkie swoje zapatrywania wtedy na świat, człowieka, ziemię itp. Sw. Paweł przejmując te poglądy sobie współczesnych, bynajmniej nie czynił z nich przedmiotu swojego nauczania. One bowiem były wszystkim powszechnie znane. Brał je z otaczającego go świata, by przy ich pomocy jaśniej i wyraźniej przedstawić problem, o który mu chodziło. Można zatem powiedzieć, że te jego wypowiedzi, oparte o światopogląd powszechnie wtedy wyznawany

23 Por. B. Mariani, Il poligenismo e s. Paolo Rom 5, 12-14, w: „Euntes Docete”, 4 (1951) $120-146$.

24 Art. cyt., 145.

25 Por. C. Hauret, Origines de l'univers et de l'homme d'après la Bible, Paris 1952, 171; Por. także na ten temat H. Haag, dz. cyt. 60-71, gdzie autor wyjaśnia sens I znaczenie parareli Adam - Chrystus, którą tak często posługuje się św. Paweł. 
miały charakter figur i porównań literackich, nic wspólnego z rzeczywistością i historią nie mających. Za takim ujęciem przemawia także wypowiedź św. Pawła z Rz 5, 14: ,a śmierć rozpanoszyła się od Adama aź do Mojżesza, nawet nad tymi, którzy nie zgrzeszyli, przestępstwem na w zó r Adama. On to jest typem, tego, który ma przyjść". Wyrażenie: „On jest typem” należy rozumieć w odniesieniu do antytypu, którym jest Chrystus. Nie zawsze typ musi oznaczać konkretną rzeczywistość ani nie przesądza i nie decyduje o jej historyczności. Niezależnie od tego, czy typ jest historyczny czy nie, paralela zachowuje swoją wartość i właściwe znaczenie. Chrystus powoływał się także w swoim nauczaniu na znak Jonasza, a przez to nie stwierdzał, czy Jonasz był, czy nie był postacią historyczną. Podobnie, gdy autor listu do hebrajczyków posługuje się zestawieniem Melchizedek - Chrystus, wcale nie wypowiada się na temat historyczności samego Melchizedeka. Gdy np. św. Piotr w swoim pierwszym liście 3, 18-22 mówi o wodach potopu, zestawiając je z wodą chrztu św. nie mówi też nic na temat historyczności potopu. W oparciu o przytoczone wyżej przykłady a także o inne, których Biblia posiada bardzo wiele, można by powiedzieć, że św. Paweł w analizowanym przez nas tekście nie interesuje się tym, czy Adam był postacią historyczną czy nie, czy istniała jedna czy więcej par ludzkich; jemu chodzi o religijne pouczenie odnośnie grzechu ludzkiego i jego życiowych konsekwencji. Cały zatem ciężar treściowy tego tekstu należy przenieść na problem grzechu, a nie na zagadnienie pochodzenia ludzi od jednej czy więcej par ludzkich.

Reasumując powyższe uwagi możemy stwierdzić, że Pismo św. nił wypowiada się w ogóle w sprawie monogenizmu czy poligenizmu, ponieważ nie jest zainteresowane stroną somatyczną człowieka. Traktując człowieka jako jedność, myśli przede wszystkim o jego zbawieniu. Jeśli jednak pewne jego wypowiedzi oparte o nasze przedrozumienie prowadzą do monogenistycznej czy poligenistycznej interpretacji Biblii, to trudności te znikają zaraz, jeśli zważymy, że w wypowiedziach biblijnych mamy do czynienia przede wszystkim ze stanem nauki z przed 2 do 3 tysięcy lat, który może być ciekawy dla historyka czy egzegety, ale nigdy nie wiążący dla teologa, a tym mniej dla antropologa czy przyrodnika.

Niezależnie jednak od tego należy stwierdzić, że poligenizm w świetle wypowiedzi biblijnych jest możliwy i kiedy zostanie ostatecznie przez naukę przyjęty jako pewnik, można go będzie pogodzić z danymi biblij. nymi na ten temat. Zdaniem wielu teologów ${ }^{26}$ nie ma także sprzeczności między poligenizmem a grzechem pierworodnym.

26 Por. M. Flick, Il poligenismo e il dogma del peccato originale, w: „Gregorianum", 28 (1947) 560-63. Także art. W. Hryniewicz, Wspótczesne dyskusje na temat poligenizmu, w: „Rocz. Teol. Kan.”, 16/2 (1969) 115-142. 